Pak. j. sci. ind. res. Ser. B: biol. sci. 201457 (1) 41-45

\title{
Comparison of Antibacterial Activity of Crude Alkaloid and Saponin Extract from Phyllanthus niruri
}

\author{
Victor Adeyinka Ajibade \\ Department of Science Technology, Microbiology Option, Federal Polytechnic, \\ P. M. B. 5351, Ado-Ekiti, Ekiti State, Nigeria \\ (received February 26, 2013; revised July 31, 2013; accepted August 5, 2013)
}

\begin{abstract}
The antibacterial activity of crude extract of saponin and alkaloid from Phyllanthus niruri was investigated and compared against some test bacteria. With the activity of saponins, Bacillus subtilis, Salmonella typhi and Klebsiella pneumoniae were resistant at concentrations of $0.01 \mathrm{mg} / \mathrm{mL}$ and $0.02 \mathrm{mg} / \mathrm{mL}$, while, they were susceptible at $0.03 \mathrm{mg} / \mathrm{mL}, 0.4 \mathrm{mg} / \mathrm{mL}$ and $0.05 \mathrm{mg} / \mathrm{mL}$ concentrations. With the activity of saponin and alkaloid, B. subtilis, K. pneumoniae and $S$. typhi were resistant at 0.01 $\mathrm{mg} / \mathrm{mL}$ concentration, while, Staphylococcus aureus was resistant to alkaloid at $0.01 \mathrm{mg} / \mathrm{mL}$ concentration but susceptible to saponin at the same concentration. Escherichia coli, Pseudomonas aeruginosa and $S$. aureus were more sensitive to saponin with diameter of zone of inhibition of $8.00 \mathrm{~mm}, 12.00 \mathrm{~mm}$ and $12.00 \mathrm{~mm}$ compared with $5.00 \mathrm{~mm}, 10.00 \mathrm{~mm}$ and $10.00 \mathrm{~mm}$, respectively, as observed in alkaloid. The test organisms were susceptible to saponin at a concentration of $0.03 \mathrm{mg} / \mathrm{mL}$. S. aureus was resistant to alkaloid; B. subtilis, E. coli, K. pneumoniae, P. aeruginosa, S. typhi and S. aureus were sensitive to both saponin and alkaloid. Combined, saponin and alkaloid showed more potency and may offer an alternative therapeutic agent against bacterial infections.
\end{abstract}

Keywords: antibacterial activity, alkaloid, Phyllanthus niruri, saponin

\section{Introduction}

Medicinal plants have been used in traditional system of medicine for hundreds of years in many countries of the world (Grewal, 2000; Agharkar, 1991). This is in line with the World Health Organization (WHO) prescription that medicinal plants warrant attention. The use of medicinal plants constitutes an important part in traditional or folkloric medicine in Africa. Modern orthodox medicine has improved the health of many people all over the world. It is noteworthy that in many cultures, modern medicine complements traditional practices in China (Natarraj, 2000).

The efficacy of phytochemicals acting as antibacterial agents have been studied for long, and cannot be under estimated (Adedapo et al., 2005). These non-nutritional components of plants have been investigated to exhibit high potency when acting in combination because their synergistic nature potentiates each other. The study carried out by Kavit et al. (2013), revealed the presence of medicinally active constituents like tannins, alkaloid, terpenoids, steroids and saponins in the leaves of $P$. fraternus. This correlates with the findings in this

E-mail: ajibvijay@yahoo.com work. The medicinal value of $P$. niruri as an antidote to $E$. coli and Salmonella infections and as a promising alternative treatment for nephrolithiasis has also been emphasised (Mirian et al., 2010).

Phyllanthus niruri originated from India, usually occurring as a winter weed during summer seasons. It is distributed throughout the tropical and subtropical areas (Ross, 1999; Farjou et al., 1987). P. niruri also known as "Chanca piedra" belongs to the family Euphorbiaceae. It is known as "enyikwonwa" in Ibo language of the south eastern part of Nigeria and popularly known as "Asasa" in Yoruba south west Nigeria. It has been confirmed that it has hypoglycemic properties (Sivaprakasm et al., 1995), used for treatment of jaundice (Khanna, et al., 2002; Farjou et al., 1987) hepatitis (Adedapo et al., 2005), dysentery, diuretic, typhoid, kidney stone, malaria, influenza, antibacterial and antiviral (Mellinger et al., 2005), and has protective action on different organs especially the liver and kidney. It also possesses lipid lowering action, antidiabetic action and antifungal action (Farjou et al., 1987). No form of toxicity has been associated with the usage of this plant extract (Barros and Zahad, 2003). P. niruri has also been considered useful to treat problems 
associated to women, such as dysmenorrhea (Khanna, et al., 2002). Saponin extracts of P. niruri have been reported to be effective against hepatitis $\mathrm{B}$ and other viral infections (Chatterjee, 2006).

The alkaloid extract of $P$. niruri showed suppressing activities on strain of HIV-1 cells cultured on MT-4 cell line (Natarraj et al., 2000).

Saponins are very potent bio-agent in plants and have been known to be very active against S.typhi and E. coli without adverse effect on cells. The analysis of blood parameters carried out on experimental rabbits treated with saponin as discussed in the antibacterial activity of saponin and alkaloid extracts from whole plant of $P$. niruri (Ajibade and Famurewa, 2012), showed that there was significant decrease in urea, uric acid and creatinine levels in urine and an eventual treatment of the infections. This may explain the use of $P$. niruri saponin to remove uric acid from urine. The potency of saponin on the test bacteria correlates with that of Ajibade and Famurewa (2011), where it was reported that the use of saponin extract from $P$. niruri do not affect the blood cells adversely even though it was potent against $S$. aureus, $S$. typhi and E. coli. The activity of the saponin extract was also found to be dose dependent. This observation was earlier reported by Corea et al. (2005); Oda et al. (2000) and Shim et al. (2000), who found that the inhibitory activity of saponin on gastric emptying was dependent on the level of serum glucose and mediated at least in part by the capsaicin-sensitive sensory nerves and the central nervous system.

Saponins, one of the phytochemicals in P. niruri are known for their hypocholesterolic (Fenwic et al., 1991), anticarcinogenic, immune boostering and antibacterial activities (Oda et al., 2000). Saponins and alkaloids extracted from $P$. niruri are very effective in vivo against infections caused by $S$. typhi and E. coli without deleterious effect on organs of the body of test rabbits (Ajibade and Egbebi, 2011; Santos,1994). This work tends to compare the potency of saponin and alkaloid extract from whole plant of $P$. niruri on clinical pathogenic microorganisms to obtain alternative therapeutic agents against these pathogens.

\section{Materials and Methods}

Collection and processing of plant material. The plant was collected from farmlands in the Federal Polytechnic Ado-Ekiti, Nigeria, during the raining season between the months of September and December,
2010. The plant was dried at room temperature $\left(27^{\circ} \mathrm{C}\right.$ $\pm 1{ }^{\circ} \mathrm{C}$ ) for three weeks then milled using centrifugal milling machine (Gallen Kamp) and stored in air-tight plastic container. Identification and authentication of plant was done in the Department of Science Technology, Federal Polytechnic Ado-Ekiti, Nigeria, where a voucher specimen (No. MED. PLT 0-2008-10) was kept.

Extraction of crude alkaloid. The method of Naik and Javekars (2003) was employed for the extraction. A $15 \mathrm{~g}$ portion of the plant material was soaked in $100 \mathrm{~mL}$ of $95 \%$ ethanol and allowed to stand for three days. The ethanol solution was filtered and evaporated under reduced pressure with Bibby rotary evaporator (EVF-530-010k) and the residue suspended in $30 \mathrm{~mL}$ distilled water. $20 \mathrm{~mL}$ chloroform was added and passed through Whatman No. 4 filter paper. The extract was dried at room temperature $\left(27^{\circ} \mathrm{C} \pm 1{ }^{\circ} \mathrm{C}\right)$ for six days and $100 \%$ sodium sulphate added to precipitate the alkaloids. The precipitate was filtered and evaporated under reduced pressure to obtain a light brown powder.

Extraction of saponin. The method described by Marston et al. (2000) was employed for this purpose. The dried and powdered plant material $(500 \mathrm{~g})$ was defatted in a Soxhlet with petroleum spirit at $40-60{ }^{\circ} \mathrm{C}$ for $16 \mathrm{~h}$. The residue was added to $100 \mathrm{~mL}$ of absolute methanol and left overnight under reflux at $70{ }^{\circ} \mathrm{C}$. It was filtered and dissolved in $100 \mathrm{~mL}$ of distilled water, extracted in a separating funnel with 1-butanol three times and dried by evaporation. Finally, the extract was dissolved in $25 \mathrm{~mL}$ of absolute methanol and saponins were precipitated by adding $75 \mathrm{~mL}$ of diethyl ether.

Collection of bacteria. Five strains each of E. coli, S. aureus, Salmonella spp, B. subtilis, K. pneumoniae and $P$. aeruginosa from different source were collected at the medical laboratory section of the University Teaching Hospital, Ado-Ekiti and sub cultured on a nutrient agar slant medium then stored in culture collection box at the Microbiology Laboratory of the Department of Science Technology, Federal Polytechnic, Ado-Ekiti, Nigeria.

Bacteriological assay. Inoculums was removed from stock culture into $5 \mathrm{~mL}$ of nutrient broth and incubated at $37{ }^{\circ} \mathrm{C}$ for $24 \mathrm{~h}$ to reactivate the bacterium. The bioassay monitoring of crude extracts was done with the agar disc diffusion technique (Denni and Hussain, 1991). Different concentrations $(0.01-0.05 \mathrm{mg} / \mathrm{mL})$ of the extracts were prepared by diluting the necessary grams in $10 \mathrm{~mL}$ of distilled water in test-tubes. Punched filter paper (Whatman No. 5) of diameter $7.0 \mathrm{~mm}$ was 
impregnated with the extracts. These were then applied to the surface of over dried nutrient agar plates, which had been seeded with an overnight culture of test organism. Plates were incubated overnight at $37^{\circ} \mathrm{C}$ and zones of inhibition estimated semi-quantitatively. Gentamycin sulphate and ampicillin (Nicholas Laboratories, U.K.) were used as positive control.

\section{Results and Discussion}

The results are shown in the Table 1-3. Diameter of zone of inhibition $(\mathrm{mm})$ of saponin at different concentrations to $B$. subtilis, E. coli, $K$. pneumonia, $P$. aeruginosa, $S$. typhi and $S$. aureus are shown in Table 1. B. subtilis and $S$. typhi were resistant at concentration of $0.01 \mathrm{mg} / \mathrm{mL}$ and $0.02 \mathrm{mg} / \mathrm{mL}$. $K$. pneumoniae was resistant at concentration $0.01 \mathrm{mg} / \mathrm{mL}$, while, others were susceptible at $0.03 \mathrm{mg} / \mathrm{mL}, 0.04$ $\mathrm{mg} / \mathrm{mL}$ and $0.05 \mathrm{mg} / \mathrm{mL}$ concentrations.

Table 2 shows the result of the potency of alkaloid extract of $P$. niruri on test bacteria at various concentrations. It was observed that $S$. aureus and $K$. pneumoniae were resistant at $0.03 \mathrm{mg} / \mathrm{mL} ;$ B. subtilis and $S$. typhi were resistant at $0.01 \mathrm{mg} / \mathrm{mL}$, while, E. coli and $P$. aeruginosa were susceptible at $0.01 \mathrm{mg} / \mathrm{mL}$. When these zones of inhibition were compared with the positive control (ampicillin), it was observed that the concentration to which the bacteria were susceptible to; had higher diameter of inhibition zone. This is an indication that the potency of the extract is higher than the ampicillin.

Table 3 shows the comparison of the potency of saponin and alkaloid to the test bacteria at different concentrations. At $0.01 \mathrm{mg} / \mathrm{mL}$, it was observed that B. subtilis, $K$. pneumoniae and $S$. typhi were resistant to both saponin and alkaloid, while, $S$. aureus was resistant to alkaloid but susceptible to saponin at the same concentration. E. coli, P. aeruginosa and S. aureus were more sensitive to saponin with MIC of $8.00 \mathrm{~mm}$, $12.00 \mathrm{~mm}$, and $12.00 \mathrm{~mm}$, respectively, as compared
Table 1. Degree of potency of different concentrations of saponin extract of $P$. niruri on bacteria

\begin{tabular}{lccccc}
\hline \hline Test organisms & \multicolumn{5}{c}{ Concentration $(\mathrm{mg} / \mathrm{mL})$} \\
\cline { 2 - 7 } & 0.01 & 0.02 & 0.03 & 0.04 & 0.05 \\
\hline Bacillus subtilis & 0.00 & 0.00 & 14.00 & 14.00 & 16.00 \\
Escherichia coli & 8.00 & 8.00 & 16.00 & 16.00 & 16.00 \\
Klebsiella pneumoniae & 0.00 & 12.00 & 15.00 & 16.00 & 18.00 \\
Pseudomonas. aeruginosa 12.00 & 12.00 & 16.00 & 16.00 & 20.00 \\
Salmonella spp. & 0.00 & 0.00 & 14.00 & 16.00 & 20.00 \\
Staphylococcus aureus & 12.00 & 14.00 & 16.00 & 16.00 & 16.00 \\
\hline \hline
\end{tabular}

Diameter of zone of inhibition by control (ampicillin) $\geq 14.00 \mathrm{~mm}$.

Table 2. Degree of potency of different concentration of alkaloid extract of $P$. niruri on bacteria

\begin{tabular}{llllll}
\hline \hline Test organisms & \multicolumn{5}{c}{ Concentration (mg/mL) } \\
\cline { 2 - 7 } & \multicolumn{5}{c}{ Diameter of zone of inhibition $(\mathrm{mm})$} \\
\hline Bacillus subtilis & 0.01 & 0.02 & 0.03 & 0.04 & 0.05 \\
Escherichia coli & 0.00 & 10.00 & 10.00 & 12.00 & 14.00 \\
Klebsiella pneumoniae & 0.00 & 0.00 & 0.00 & 10.00 & 14.00 \\
Pseudomonas aeruginosa & 10.00 & 12.00 & 14.00 & 14.00 & 14.00 \\
Salmonella spp. & 0.00 & 10.00 & 14.00 & 20.00 & 24.00 \\
Staphylococcus aureus & 0.00 & 0.00 & 0.00 & 0.00 & 0.00 \\
\hline \hline
\end{tabular}

Diameter of zone of inhibition by control (ampicillin) $\geq 14.00 \mathrm{~mm}$.

with $5.00 \mathrm{~mm}, 10.00 \mathrm{~mm}$ and $10.00 \mathrm{~mm}$, respectively, observed in alkaloid. At $0.03 \mathrm{mg} / \mathrm{mL}$, it was observed that $K$. pneumoniae and $S$. aureus were resistant to alkaloid, while B. subtilis, E. coli, P. aeruginosa and S. typhi were susceptible with MIC $10.00 \mathrm{~mm}, 10.00$ $\mathrm{mm}, 14.00 \mathrm{~mm}, 14.00 \mathrm{~mm}$, respectively. The entire test organisms were susceptible to saponin at this concentration. At $0.05 \mathrm{mg} / \mathrm{mL}$, it was observed that only $S$. aureus was resistant to alkaloid, B. subtilis, E. coli, K. pneumoniae, P. aeruginosa, S. typhi and $S$. aureus were sensitive to both saponin and alkaloid, while, one isolate of $S$. aureus was resistant to alkaloid. The resistance of this isolate could be ascribed to the

Table 3. Comparison of the degree of potency of saponin and alkaloid at different concentrations

\begin{tabular}{|c|c|c|c|c|c|c|}
\hline \multirow[t]{2}{*}{ Test organisms } & Saponin & Alkaloid & Saponin & Alkaloid & Saponin & Alkaloid \\
\hline & \multicolumn{2}{|c|}{$(0.01 \mathrm{mg} / \mathrm{mL})$} & \multicolumn{2}{|c|}{$(0.03 \mathrm{mg} / \mathrm{mL})$} & \multicolumn{2}{|c|}{$(0.05 \mathrm{mg} / \mathrm{mL})$} \\
\hline Bacillus subtilis & 0.00 & 0.00 & 14.00 & 10.00 & 16.00 & 14.00 \\
\hline Escherichia coli & 8.00 & 5.00 & 16.00 & 10.00 & 16.00 & 16.00 \\
\hline Klebsiella pneumoniae & 0.00 & 0.00 & 15.00 & 0.00 & 18.00 & 14.00 \\
\hline Pseudomonas aeruginosa & 12.00 & 10.00 & 16.00 & 14.00 & 20.00 & 14.00 \\
\hline Salmonella spp. & 0.00 & 0.00 & 14.00 & 14.00 & 20.00 & 24.00 \\
\hline Staphylococcus aureus & 12.00 & 10.00 & 16.00 & 0.00 & 16.00 & 30.00 \\
\hline
\end{tabular}


acquisition of resistant factor, importation and transmission of new strains.

Alkaloids have also been known to be potent against enteropathogenic E. coli (Juvekar, 2003). However, the potency of saponin against the test bacteria in this work seems to be higher than that of the alkaloid as shown in Table 3. With the observed results, the activity of the extracts when used singly shown significant efficacy, but high potency was, however, exhibited when they were combined. It was therefore, concluded that the combination of these phytochemicals would serve the useful purpose of treating diseases caused by $S$. typhi, B. subtilis, P. aeruginosa and $K$. pneumoniae or from which these microorganisms have been isolated.

\section{References}

Adedapo, A.A., Asegbayibi, A.Y., Emikpe, B.O. 2005. Some clinic-pathological changes associated with the aqueous extract of the leaves of Phyllanthus niruri in rats. Interscience Journal, 40: 119-122.

Ajibade, V.A., Famurewa, O. 2012. Histopathological and toxicological effects of crude saponin extract from Phyllanthus niruri, L (Syn. P. franternus Webster) on Organs in animal studies. Global Journal for Medical Research, 12: 31-38.

Ajibade, V.A., Egbebi, A.O. 2011. Effect of alkaloid extract of Phyllanthus niruri on rabbits infected with enteropathogenic Escherichia coli. International Journal of Tropical Medicine and Public Health, 1: 33-39.

Ajibade, V. A., Famurewa, O. 2011. Antibacterial activity of saponin and alkaloid extraction from whole plant of Phyllanthus niruri L. (Syn. P. franternus Webster). Pakistan Journal of Scientific and Industrial Research, 54: 47-52.

Agharkar, S.P. 1991. Medicinal Plants of Bombay Presidency, 279 pp., Scientific Publishers, Jodhpur, India.

Barros, M.E., Zahad, G. 2003. Plants with oral hypoglycaemic action. Journal of Crude Research, 17: 139-196.

Chatterjee, M. 2006. Herbal (Phyllanthus niruri) protein isolate protects liver from nimesulide induced oxidative stress. Pathophysiology, 13: 95-102.

Corea, G., Fattorusso, E., Lanzotti, V., Capasso, R., Izzo, A.A. 2005. Antispasmodic saponins from bulbs of red onion Allium cepa L.var.Tropea. Journal of Agriculture and Food Chemistry, 53: 935-940.
Denni, Y., Hussain, H. 1991. Screening for antimicrobial activity and for alkaloids of Nauclea latifolia. Journal of Ethnopharmacology, 35: 91-96.

Farjou, I.B., Al-Ani, M., Guiges, S.Y. 1987. Lowering of blood glucose in diabetic rabbits by Artemisia extract. Journal of Faculty Medicine, 92: 137-141.

Fenwick, G.R., Price, K.R., Tsukamoto, C., Okubo, K. 1991. Saponins. In: Toxic Substances in Crop Plants, J. P. D' Mello, C.M. Duffus and J. H. Duffus, pp.285327, Royal Society of Chemistry, Cambridge, UK.

Grewal, R.C. 2000. Medicinal Plants, pp. 298-304, $1^{\text {st }}$ edition, Campus Book International, New Delhi, India.

Juvekar, A.R. 2003. Effects of alkaloid extract of Phyllanthus niruri on HIV replication. Indian Journal of Medical Sciences, 57: 387-393.

Kavit, M., Patel, B.N., Jain, B.K. 2013. Phytochemical analysis of leaf extract of Phyllanthus fraternus. Research Journal of Recent Sciences, 2(ISC2012): $12-15$.

Khanna, A.K., Rizvi, F., Chander, R. 2002. Lipid lowering activity of Phyllanthus niruri in hyperlipemic rats. Journal of Ethnopharmacology, 82: 19-22.

Mellinger, C.G., Carbonero, E.R., Cipriani, T.R., Gorin, P.A., Lacommi, M. 2005. Xylans from the medicinal herb Phyllanthus niruri. Journal of Natural Products, 68: 129-132.

Marston, A., Wolfender, H., Hostettmann, K. 2000. Analysis and isolation of saponins from plant material. In: Saponins in Food, Feedstuffs and Medicinal Plants, Proceedings of the Phytochemical Society of Europe, W. Olezek and A. Marston, (eds.), vol. 45, pp. 1-12, Springer Netherlands.

Mirian, A.B., Ita, P.H., Nestor, S. 2010. Phyllanthus niruri as a promising alternative treatment for nephrolithiasis. International Brazilian Journal of Urology, 36: 657-664.

Natarraj, C.G. 2000. Role of herbal extracts in HIV infected patients. Proceedings of International Congress on Ayurveda, 207 pp.

Naik, A.D., Juvekar, A.R. 2003. Effects of alkaloid extract of $P$. niruri on HIV replication. Indian Journal of Medical Sciences, 57: 387-393.

Oda, K., Matsuda, H., Murakami, T., Katayama, S., Ohgifani, T., Yoshikawa, M. 2000. Adjuvant and haemolytic activities of 47 saponins derived from medicinal and food plants. Biological Chemistry, 381: 67-74.

Ross, I. A. 1999. Medicinal Plants of the World: Chemical Constituents, Traditional and Modern 
Medicinal Uses, vol. 3, pp. 249-252, Humana Press, New Jersey (Totowa), USA.

Santos, A.R. 1994. Analysis effects of callus culture extracts from selected species of Phyllanthus in mice. Journal of Pharmaceutical Pharmacology, 46: 755-759.

Shim, I., Javaid, J.I., Kim, S.E. 2000. Effect of ginseng total saponin on extracellular dopamine release elicited by local infusion of nicotine into the striatum of freely moving rats. Planta Medica, 66: 705-708.

Sivaprakasam, K., Yasodha, R., Sivanandam, G., Veluchamy, G. 1995. Clinical evaluation of Phyllanthus amarus Schum and Thonn in diabetes mellitus. In: Proceedings of the Seminar on Research in Ayurveda and Siddha, 7 pp., CCRAS, New Delhi, India 